\title{
"Technology for the development and implementation of social projects: substantiation of the project proposal and documents"
}

\begin{tabular}{|c|c|}
\hline AUTHORS & $\begin{array}{l}\text { Nataliia Ahramakova (D https://orcid.org/0000-0002-4207-2091 } \\
\text { R http://www.researcherid.com/rid/AAG-8386-2020 } \\
\text { Svitlana Honcharova (D https://orcid.org/0000-0002-2463-8290 } \\
\text { R http://www.researcherid.com/rid/AAG-8421-2020 } \\
\text { Andriy Honcharov (D https://orcid.org/0000-0003-0799-4856 } \\
\text { R http://www.researcherid.com/rid/AAH-2499-2020 }\end{array}$ \\
\hline ARTICLE INFO & $\begin{array}{l}\text { Nataliia Ahramakova, Svitlana Honcharova and Andriy Honcharov (2020). } \\
\text { Technology for the development and implementation of social projects: } \\
\text { substantiation of the project proposal and documents. Development } \\
\text { Management, 18(1), 11-24. doi:10.21511/dm.18(1).2020.02 }\end{array}$ \\
\hline DOI & http://dx.doi.org/10.21511/dm.18(1).2020.02 \\
\hline RELEASED ON & Monday, 15 June 2020 \\
\hline RECEIVED ON & Friday, 03 April 2020 \\
\hline ACCEPTED ON & Saturday, 09 May 2020 \\
\hline LICENSE & $\begin{array}{l}(c) E Y \\
\text { This work is licensed under a Creative Commons Attribution } 4.0 \text { International } \\
\text { License }\end{array}$ \\
\hline JOURNAL & "Development Management" \\
\hline ISSN PRINT & 2413-9610 \\
\hline ISSN ONLINE & $2663-2365$ \\
\hline PUBLISHER & LLC "Consulting Publishing Company "Business Perspectives" \\
\hline FOUNDER & Simon Kuznets Kharkiv National University of Economics \\
\hline
\end{tabular}

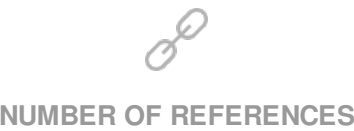

18
NUMBER OF FIGURES

3
NUMBER OF TABLES

3

(C) The author(s) 2021. This publication is an open access article. 


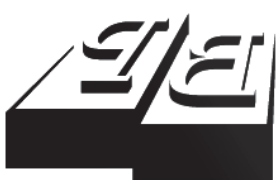

BUSINESS PERSPECTIVES

Publisher

LLC "CPC "Business Perspectives" Hryhorii Skovoroda lane, 10, Sumy, 40022, Ukraine www.businessperspectives.org

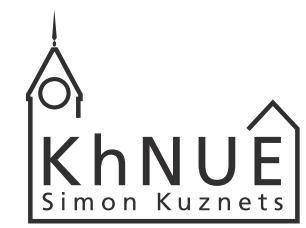

S. KUZNETS KHNUE

Founder

Simon Kuznets Kharkiv National University of Economics, Nauky avenue, 9-A, Kharkiv, 61166,

Ukraine

http://www.hneu.edu.ua/

Received on: 3th of April, 2020 Accepted on: 9th of May, 2020 Published on: 15th of June, 2020

(c) Nataliia Ahramakova,

Svitlana Honcharova,

Andriy Honcharov, 2020

Nataliia Ahramakova, Associate Professor, Ph.D. (Economics), Candidate of Economic Science, Faculty of Economy and Law, Department of Economics and Social Sciences, Simon Kuznets Kharkiv National University of Economics, Ukraine.

Svitlana Honcharova, Associate Professor, Ph.D. (Economics), Candidate of Economic Science,

Faculty of Economy and Law,

Department of Economics and Social Sciences, Simon Kuznets Kharkiv National University of Economics,

Ukraine.

Andriy Honcharov, Associate Professor, Ph.D. (Economics), Candidate of Economic Science, Faculty of Management and Business, Department of Management and Administration, Kharkov State Academy of Culture, Ukraine.

\section{(c) (i)}

This is an Open Access article, distributed under the terms of the Creative Commons Attribution 4.0 International license, which permits unrestricted re-use, distribution, and reproduction in any medium, provided the original work is properly cited.
Nataliia Ahramakova (Ukraine), Svitlana Honcharova (Ukraine), Andriy Honcharov (Ukraine)

\section{TECHNOLOGY FOR THE DEVELOPMENT AND IMPLEMENTATION OF SOCIAL PROJECTS: SUBSTANTIATION OF THE PROJECT PROPOSAL AND DOCUMENTS}

\begin{abstract}
Ensuring a decent standard of living for citizens, especially vulnerable groups, requires qualitative changes in society. Social projects are a modern tool for making change. In this regard, it becomes relevant to study the applied aspect of their implementation - technology for the development and implementation of social projects. This study aims at exploring the nature and classification of social projects, as well as improving and further developing the technology for the development and implementation with justification of the project proposal and documentation using the Let's Start Together project as an example. The object of research is the process of using technologies for the development and implementation of social projects in solving social problems of society. The subject is theoretical and practical recommendations on the technology for the development and implementation of social projects, based on the justification of the project proposal and documentation. The following methods were used: logical analysis - to clarify the essence of the concept of a social project; analysis and synthesis - to improve the classification of social projects; network planning - to formulate a technology implementation plan for the development and implementation of social projects. The paper explores the essence of a social project, proposes the classification of social projects and defines criteria for their evaluation. The sources of financing a social project are characterized; co-financing by various donors. A technology for the development and implementation of social projects is proposed. Considerable attention is paid to the first stage, namely the development of the project proposal and the documentation of a social project. The proposed technology was tested in the context of the social project Let's Start Together.
\end{abstract}

\section{Keywords}

JEL Classification

Н. В. Аграмакова (Україна), С. Ю. Гончарова (Україна),

А. Б. Гончаров (Україна)

\section{ТЕХНОЛОГІЯ РОЗРОБКИ ТА РЕАЛІЗАЦІЇ СОЦІАЛЬНИХ ПРОЕКТІВ: ОБҐРУНТУВАННЯ ПРОЕКТНОЇ ПРОПОЗИЦІї ТА ДОКУМЕНТАЦІЇ}

\begin{abstract}
Анотація
Забезпечення гідного рівня життя громадян, особливо вразливих груп населення, потребує якісних перемін у житті суспільства. Сучасним інструментом впровадження інноваційних змін є соціальні проєкти. У зв'язку з цим актуальним стає вирішення важливого наукового завдання - вдосконалення технології розробки та реалізації соціальних проєктів, а також практичного - обгрунтування проєктної пропозиції та документації. Мета дослідження полягає в удосконаленні технології розробки та реалізації соціальних проєктів шляхом упорядкування та уточнення послідовності й змісту відповідних етапів та практичної реалізації етапу «обгрунтування проєктної пропозиції та документації» на прикладі проєкту «Стартуємо разом!». Об'єкт дослідження - процес удосконалення технології розробки та реалізації соціальних проєктів при вирішенні суспільних проблем. Предмет дослідження - теоретичні та практичні рекомендації щодо технології розробки та реалізації соціальних проєктів на основі
\end{abstract}


обгрунтування проєктної пропозиції та документації. Використано методи: аналізу і синтезу - для удосконалення класифікації соціальних проєктів; сітьового планування - для розробки плану впровадження технології розробки та реалізації соціальних проєктів у практичну діяльність. У роботі удосконалена класифікація соціальних проєктів за рахунок доповнення двома класифікаційними ознаками: «елементи соціальної інфраструктури» та «цільова група вразливих верств населення», що дає можливість враховувати його спрямованість при розробці проєктної пропозиції та документації, а також визначенні джерел фінансування. Досліджено критерії оцінювання соціальних проєктів. Охарактеризовано джерела фінансування соціального проєкту; співфінансування різними донорами. Удосконалена технологія розробки та реалізації соціальних проєктів шляхом упорядкування та уточнення послідовності й змісту відповідних етапів (розроблення проєктної пропозиції та документації; підготовчий; функціональний; підсумовуючий). Запропонований підхід відповідає досвіду провідних країн та критеріям експертного оцінювання та забезпечує можливість їі використання як прикладного інструменту вирішення суспільних проблем та забезпечення стійкого розвитку. Значна увага приділена першому етапу, а саме розробці проєктної пропозиції та документації соціального проєкту. На прикладі проєкту «Стартуємо разом!» проведена його апробація.

\section{Ключові слова}

вразливі групи населення, соціальний проєкт, джерела фінансування, технологія розробки та реалізації, розробка проєктної пропозиції та документації

\section{Класифікація JEL $\quad$ I38, L31, Ø35}

\section{ВСТУП}

3 метою забезпечення гідного рівня життя громадян і задоволення потреб вразливих груп населення, в умовах соціально орієнтованої ринкової економіки, широко використовується інструмент соціального проєктування. Він дозволяє вирішувати найгостріші соціальні проблеми завдяки зусиллям як державних, та і недержавних інституцій (міжнародним програмам (Програма OOH, UNISEF, USAID тощо), програмам Європейського Союзу (наприклад, «Erasmus+», «U-LEAD з Європою»), міжнародним фондам (наприклад, Відродження), українським благодійним фондам, підприємствам, окремим меценатам та громадським організаціям). Останнім часом відзначається підвищений інтерес до питань управління соціальними проєктами в різних сферах життєдіяльності держави і суспільства. Проєктна діяльність передбачає перетворення соціального середовища, використання інноваційних інструментів та будується на застосуванні відповідної технології, яку можна уніфікувати, вдосконалити та впровадити. Тому актуальним є удосконалення технології щодо розробки та реалізації соціальних проєктів.

\section{1. ЛІТЕРАТУРНИЙ ОГЛЯА}

Теоретичні основи управління проєктами проаналізовано у працях: Мартинишиної та Костюченко (доведено,щопроєктнийменеджментєстратегічнимінструментомрозвиткусоціокультурноїсфери),Лутай та Баранецької (обгрунтовано рекомендації щодо впровадження та вдосконалення процесу управління проєктами в організаціях публічної та соціальної сфер), Клешні (здійснено культур-філософський аналіз соціального проєктування у контексті культурно-цивілізаційного процесу розгортання інформаційної доби), Алейнікової (розглянуто питання підвищення конкурентоспроможності проєктно-орієнтованих структур і організацій шляхом використання стратегій управління інноваційним розвитком), Антонюка та Буйя (досліджено прикладні форми застосування соціальних інновацій та досвід реалізації проєктів провідних країн світу для України) та інші.

Різноманітні аспекти соціального проєктування для вразливих груп населення знайшли відображення у працях Панчиної (досліджено особливості проєктування спеціальних об'єктів для соціальнонезахищених груп населення), Філімонова (окреслено проблеми обмеженості та недостатності фінансування соціальних проєктів для людей з особливими потребами), Гевчука (проаналізовано соціально-педагогічні проєкти та програми роботи з дітьми трудових мігрантів в Україні), Пилипенко, Романової (розглянуто міжнародні соціальні проєкти у сфері соціальної роботи зі споживачами ін'єкційних наркотиків) та ін.

Проєктуванням територіальних громад займаються Богданов (проаналізовано сучасні наукові підходи до проєктування соціально-економічного розвитку територій), Бовкун (досліджено бюджетне та стратегічне планування соціально-економічного розвитку управління інфраструктурним проєктом територіальних громад), Гусятинський, Ковальчук (розглянуто особливості управління проєктами 
соціально-економічного розвитку населених пунктів»), Добрівський (визначено соціальний проєкт як інструмент реалізації інноваційного та самоврядного потенціалу територіальної громади малого міста), Шмиголь, Антонюк, Явор (розроблена методика складання бюджетів муніципальних соціальних проєк тів), Родченко, Гуца (запропоновано підхід до розробки та реалізації проєктів соціально-економічного розвитку територіальних громад) та інші науковці.

Питання оцінки соціальних проєктів та їх експертизи віддзеркалені у працях Нагорної (розроблено критерії для оцінювання у процесі соціального проєктування, методику моніторингу та оцінювання), Чернова (удосконалено методологію соціальної експертизи публічних проєктів у регіональному управлінні).

Технологію розробки соціального проєкту та дослідження окремих її етапів бачимо у працях Гевчука, Синюка, Кропельницької, Миговича, Кулеша-Любінця та інших. Однак, технологія розробки та реалізації соціальних проєктів потребує більш детальної розробки з урахуванням досвіду провідних країн та критеріїв експертного оцінювання, можливостей для практичного використання.

\section{2. МЕТА ДОСЛІДЖЕННЯ}

Мета дослідження полягає в удосконаленні технології розробки та реалізації соціальних проєктів шляхом упорядкування та уточнення послідовності й змісту відповідних етапів та практичної реалізації етапу «обгрунтування проєктної пропозиції та документації».

\section{3. МЕТОДИ ДОСЛІДЖЕННЯ}

Аналізу і синтезу - для удосконалення класифікації соціальних проєктів; сітьового планування - для розробки плану впровадження технології розробки та реалізації соціальних проєктів у практичну діяльність.

\section{4. РЕЗУЛЬТАТИ}

У загальному вигляді проєкт - це сукупність скоординованих дій із певними точками відліку та закінчення з метою досягнення певних цілей із встановленими строками, витратами та параметрами виконання. У свою чергу соціальний проєкт - сконструйоване соціальне нововведення, метою якого є створення, модернізація чи підтримка в середовищі матеріальної або духовної цінності, яка має просторово-часові та ресурсні обмеження і вплив якої на людей визнається позитивним за своїм соціальним значенням (узагальнено за $[2,4,10,16])$.

Науковці виокремлюють наступні види соціальних проєктів:

- за ступенем інноваційності: інноваційний, підтримуючий;

- за швидкістю впливу: проєкти розвитку, проєкти «швидкого реагування»;

- за джерелом фінансування: за рахунок власних коштів організації, грантовий, спонсорський, бюджетний, інвестиційний, кредитний, благодійний, за рахунок членських внесків, не потребує фінансування;

- за строком реалізації (тривалістю): короткостроковий, середньостроковий, довгостроковий;

- за розміром: мікропроєкт, малий проєкт, середній проєкт, великий проєкт, мегапроєкт;

- за рівнем та територією реалізації: міжнародний, національний, регіональний, обласний, міський (районний), селищний проєкт, на рівні певного підприємства / організації тощо $[2,10,16]$. 
Авторами удосконалена класифікація соціальних проєктів за рахунок їі доповнення двома класифікаційними ознаками:

1) за елементами соціальної інфраструктури: соціальне забезпечення, молодь, освіта, охорона здоров’я, екологічний захист, культура, функціонування громад;

2) за цільовою групою вразливих верств населення: особи з інвалідністю, пенсіонери, діти, молодь, сім’ї з дітьми, внутрішньо переміщені особи, бездомні, ВІЛ-інфіковані люди та їхні родини тощо.

Такий підхід дає можливість враховувати спрямованість соціального проєкту при розробці проєктної пропозиції та документації, а також визначенні джерел фінансування.

Розглянемо, за якими напрямками в Україні, останнім часом, оголошено прийом заявок на участь в міжнародних/національних програмах, грантах, конкурсах соціальних проєктів (Таблиця 1).

Таблиця 1. Основні напрямки реалізації соціальних проєктів

Джерело: Складено на основі [6, 7, 9, 13, 18].

\begin{tabular}{|c|c|}
\hline Напрямки & Назва програми та ініціатор \\
\hline 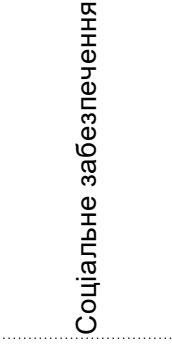 & $\begin{array}{l}\text { • проєкти щодо розвитку волонтерства в Україні; } \\
\text { проєкти щодо поліпшення умов життя вразливих верств населення (наприклад, Посольство Німеччини в } \\
\text { Україні та інші); } \\
\text { проєкт «Жінки України: залучені, спроможні, незламні»; } \\
\text { - } \quad \text { конкурс соціальної відеореклами «чесність починається з тебе»; } \\
\text { грантова допомога за проєктами людської безпеки (наприклад, програма «Кусаноне»); } \\
\text { проєкти щодо освіти та просвітнццкої діяльність з прав людини, особливо вразливих груп } \\
\text { населення, захист прав людини, просування рівності та недискримінації в українському суспільстві } \\
\text { (наприклад, міжнародний фонд Відродження тощо) та інші. }\end{array}$ \\
\hline 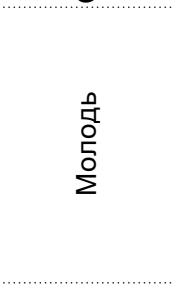 & $\begin{array}{ll}\text { - } & \text { програмии щодо підтримки молодіжних проєктів та ініціатив; } \\
\text { проєкти та програми, що об'єднують українську молодь у мережу активних громадян } \\
\text { (наприклад, волонтерська програма «Будуємо Україну Разом», проєкт «Молодіжна столиця України»); } \\
\text { фрорум молодіжних працівників та працівниць; } \\
\text { - проєкти щодо участі молоді в процесах демократизації; } \\
\text { - } \\
\text { проєкти щодо змістовного дозвілля для молоді та молодіжне таборування; } \\
\text { проєкти щодо інклюзивного розвитку (включення вразливих груп молоді); }\end{array}$ \\
\hline 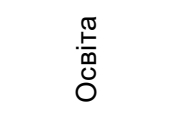 & $\begin{array}{l}\text { Створення соціальних місць для навчання } \\
\text { підтримку реалізації проєктів за напрямом } \\
\text { інвестицій «Україна - житниця майбутньогс }\end{array}$ \\
\hline 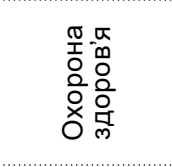 & $\begin{array}{l}\text { Програми, які спрямовані на сприяння формуванню економічно ефективної та недискримінаційної системи } \\
\text { охорони здоров'я, прозорому й раціональному використанню бюджетних коштів, забезпеченню рівного доступу } \\
\text { громадян, у тому числі представників уразливих груп, до життєво необхідних лікарських засобів і відповідного } \\
\text { лікування (наприклад, «Громадське здоров'я», Міжнародний фонд Відродження); стажування медичних } \\
\text { працівників (наприклад, АUМF (American Ukrainian Medical) тощо) та інші. }\end{array}$ \\
\hline 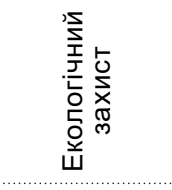 & $\begin{array}{l}\text { п посування екологічних тем, захист біорізноманіття та боротьби проти зміни клімату (наприклад, Програма } \\
\text { молодих лідерів у Брюсселі від European Commission, міжнародний фонд Відродження та інші); } \\
\text { захист тварин (асоціація зоозахисних організацій України, яка включає } 41 \text { громадську організацію); } \\
\text { проєкти щодо впровадження принципів Zero Waste («нуль відходів»). }\end{array}$ \\
\hline 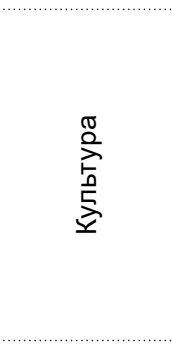 & 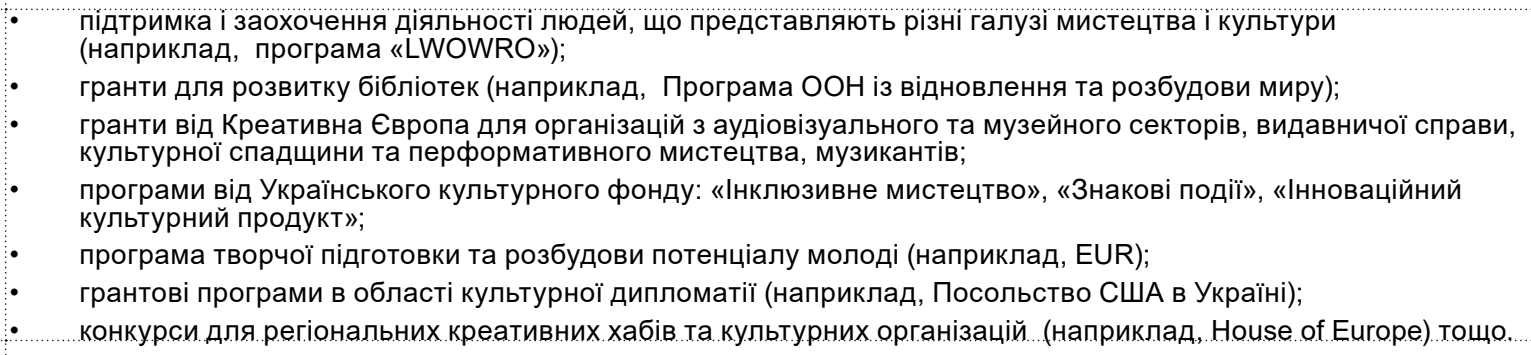 \\
\hline 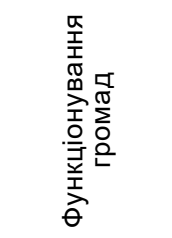 & $\begin{array}{l}\text { проєкти щодо створення молодіжних центрів у своїй громаді (наприклад, програма DOBRE та громадська } \\
\text { організація «Молодіжна Платформа»); } \\
\text { розвитку міст та покращення якості життя мешканців (наприклад, Urban Space 500; освітній проєкт для } \\
\text { посилення урбаністичних рухів України та Німеччини); } \\
\text { створення дієвих інструментів боротьби з корупцією та підвищення підзвітності державної влади перед } \\
\text { громадянам (наприклад, міжнародний фонд Відродження) та інші. }\end{array}$ \\
\hline
\end{tabular}


Угрупованні дані Таблиці 1 дозволяють наочно побачити основні напрямки, за якими пропонується розробка та реалізація соціальних проєктів для участі в міжнародних / національнихпрограмах (проєктах, грантах, конкурсах). У культурній сфері можна побачити найбільшу зацікавленість міжнародних та вітчизняних донорів. Другою є екологічний захист, оскільки це світова проблема та боротися з нею потрібно у кожному куточку земної кулі. Дуже рідко зустрічаються програми (проєкти, гранти, конкурси) за наступними напрямками: здоровий спосіб життя та зайнятість, як загалом працездатного населення, так і вразливих груп.

Важливим питанням при розгляді соціального проєктує джерела його фінансування, «формування дієвої моделі залучення капіталовкладень і забезпечення належного рівня узгодженості дій всіх зацікавлених сторін, ефективних механізмів організації і виконання проєктів», - зазначає Бугрова [3].

Перевага віддається тим проєктам, які мають співфінансування. Донорами можуть виступати: Програма OOH, UNISEF, USAID, European Commission, Посольство Німеччини, США, Фінляндії та інших країн в Україні, Креативна Європа, програма Європейського Союзу «Erasmus+», програма «U-LEAD з Європою», «Горизонт 2020», Collective Awareness Platform, міжнародний фонд Відродження, AUMF (American Ukrainian Medical), проєкт Active Citizens Ukraine «Рівні можливості для кращого майбутнього», органи місцевої влади, українські благодійні фонди, підприємства, Український культурний фонд, окремі меценати та громадські організації $[1,2,5,11]$.

Втілення у життя соціального проєкту передбачає реалізацію відповідної технології.

Питання технології розробки та реалізації соціальних проєктів досліджуються науковцями, однак дане питання потребує упорядкування та уточнення з точки зору послідовності й змісту відповідних етапів.

Технологія розробки та реалізації соціальних проєктів (узагальнено за $[8,14,17])$ :

1 етап - розроблення проєктної пропозиції та документації соціального проєкту:

- ідентифікація;

- загальний опис;

- фінансове обгрунтування.

2 етап - підготовчий:

- проєктний: впровадження технології розробки та реалізації соціальних проєктів відбувається за допомогою таких загально відомих методів сітьового графіка, діаграми Ганта тощо. Плануються роботи проєктного характеру: тривалість виконання робіт, їх вартість, можливі розміри економії часу або грошових коштів, а також визначаються операції, виконання яких не можна відстрочити, не затримавши при цьому термін впровадження проєкту в цілому. Реалізація відбувається в три етапи:

1) розчленовування проєкту на ряд окремих робіт (або операцій);

2) оцінка тривалості виконання кожної операції;

3) складання календарного плану виконання проєкту та виділення робіт, які визначають завершення виконання проєкту в цілому;

4) оцінка потреби кожної операції в ресурсах, перегляд плану виконання операцій з урахуванням забезпечення ресурсами або перерозподіл грошових або інших ресурсів.

- фінансовий: вирішення питання щодо фінансування соціального проєкту. У відповідності до рекомендацій міжнародних експертів їх впровадження відбувається на партнерських засадах щодо співфінансування. Загалом бюджет затвердженого соціального проєкту розподіляється наступним чином (Рисунок 1).

- організаційно-управлінський: На даному етапі необхідно провести підбір кандидатів у відповідності до сформованої організаційної структури, скласти план діяльності кожного структурного підрозділу. Також необхідно скласти штатний розклад з урахуванням існуючих посад, посадові інструкції спеціалістів. 
3 етап - функціональний: виконання завдань співробітниками за складеними планами, координація роботи.

4 етап - підсумовуючий: підведення підсумків розробки та реалізації соціальних проєктів включає аналіз і обговорення запланованих та досягнутих результатів. На підставі отриманих висновків стає можливим ухвалення управлінських рішень, які спрямовані на коректування виявлених недоліків і проблемних ситуацій, визначення стратегії подальшого розвитку $[12,13]$.

Поетапне впровадження наведеної технології дозволяє реалізувати соціальний проєкт, однак його подальше функціонування потребує повернення до першого етапу та виправлення певних недоліків або внесення певних змін для подальшого розвитку.

Таким чином, основними етапами технології розробки та реалізації соціальних проєктів є: розроблення проєктної пропозиції та документації соціального проєкту; підготовчий; функціональний; підсумовуючий.

3 точки зору практичної значущості реалізовано перший етап - розроблення проєктної пропозиції та документації соціального проєкту (Рисунок 2).

Далі, на певному прикладі, поведемо розроблення проєктної пропозиції та документації соціального проєкту.

1 етап - Ідентифікація соціального проєкту починається з формулювання назви соціального проєкту: «Стартуємо разом!».

Мета соціального проєкту «Стартуємо разом!» - надати всебічну допомогу молоді щодо вирішення питань працевлаштування шляхом обгрунтованого вибору ЗВО та спеціальності (що віддзеркалюють його схильності, побажання та потреби сучасного ринку праці) та професії (що відповідає отриманій освіті та $є$ перспективною для вдалого старту кар'єри) у навчально-консультаційному центрі (НКЦ) для молоді «Вдалий старт».

\section{Завдання:}

1) створитицентрінформаційнихпослугуякомумолодь зможедізнатися пропотреби тасучасні тенденціїринкупраців умовахмережевоїекономіки тавпливуінформаційно-комунікаційних технологій;

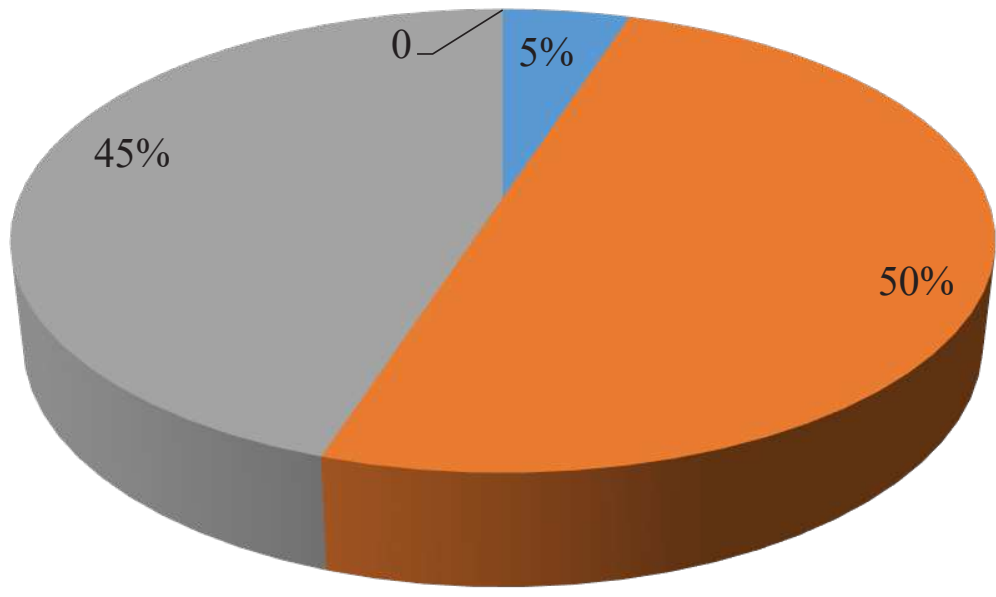

п частка власних коштів

- частка коштів, залучених за рахунок грантової угоди ЄС/ ПРООН, max

частка коштів місцевого бюджету, залучених до впровадження

Рисунок 1. Співфінансування бюджету затвердженого соціального проєкту 
2) впровадити послуги профорієнтаційного тестування за ліцензійною програмою «Профорієнтатор$\mathrm{UA»} \mathrm{за} \mathrm{результатами} \mathrm{якого} \mathrm{виявляються} \mathrm{схильності} \mathrm{та} \mathrm{особистісні} \mathrm{професійно} \mathrm{важливі} \mathrm{якості} \mathrm{молоді}$ 3 подальшою поглибленою консультацією щодо вибору начального закладу;

3) підбір вакансій для випускників навчальних закладів, згідно побажань та результатів діагностики «Профкар'єра», допомога у написанні резюме та мотиваційного письма;

4) проведення заходів 3 підвищення навичок із працевлаштування (тренінг «Від шукача до співробітника (алгоритм пошуку роботи)», семінари, майстер-класи);

5) організація ефективної взаємодії з ЗВО та роботодавцями;

6) проведення заходів з розвитку навичок soft-skills (курс «Soft-skills» тренінги, семінари, майстер-класи);

7) проведення круглих столів/робочих зустрічей (наприклад, на тему «Соціальне партнерство як важлива складова організації ефективної профорієнтаційної роботи з населенням»);

8) консультації для ознайомлення з онлайн-платформами для безкоштовного навчання («LingvaSkills», «Prometheus», «Skills Academy»);

9) профорієнтаційні уроки (наприклад, на тему «Уроки реального трудового життя», «Професії майбутнього», дні відкритих дверей, презентації навчальних закладів (можуть бути в формі відеопрезентації, он-лайн екскурсії);

10) інтерактивні заходи для молоді (профорієнтаційний квест, брейн-рінг, аукціон професій, дискусії, наприклад, на тему «Як правильно обирати професію?», профорієнтаційні ігри тощо);

11) профінформаційні семінари для батьків «Роль батьків у професійному самовизначенні школярів»;

12) профінформаційні семінари для працівників закладів освіти, наприклад, «Профорієнтаційна робота з учнівською молоддю - турбота спільна.

Передумови. Інтелектуальний і професійний потенціал будь-якої держави складає молодь. Вихід української економіки 3 глибокої соціально-економічної кризи та їїінтеграція до світового простору потребують не тільки покращення розвитку економіки, а й реформування ринку праці. В першу чергу це потрібно зробити за рахунок підвищення конкурентоспроможності молоді на ньому. В соціальному проєкті «Стартуємо разом!» для цього передбачено чотири етапи роботи з молоддю: інформаційний, діагностико-консультативний, розвиваючий, активізуючий, які реалізуються при виконанні поставлених завдань.

Опис сучасного стану проблеми, на розв’язання якої спрямовано проєкт. Сучасні процеси трансформації суспільства та світова економіка відчувають всебільший вплив інформаційно-комунікаційних технологій. В нашежиття входять поняття «інформаційне» або «мережеве» суспільство. Цевідкриває новий потенціал для перевтілення ринку праці, оскільки з'являються нові професії, актуальними стають нові компетенції. Підвищення рівня інтелектуалізації праці з необхідністю посилення освітнього та кваліфікаційного рівня фахівців, створення нових видів праці та професій, сегментів ринку праці, розвиток самозайнятості та інші фактори потребують від майбутніх школярів усвідомленого, обгрунтованого вибору навчального закладу та спеціальності. Оскільки це стане запорукою для побудови подальшої вдалої кар'єри. Крім того, отримавши після закінчення навчального закладу диплом, молоді фахівці вкрай розгубленими виходять на ринок праці. Відсутність досвіду роботи, не розуміння потреб ринку праці, різноманіття назв професій, невідповідність компетенцій, які отримали під час навчання потребам роботодавців, невміння презентувати себе на співбесіді, відсутність навичок працевлаштування все це знижує конкурентоздатність молодих фахівців на ринку праці. Отже, створення навчально-консультаційного центру для молоді «Вдалий старт» буде сприяти вирішенню нагальної соціальної проблеми щодо врегулюванні процесу працевлаштування молоді з використанням сучасних методів та інструментів, що відповідають особливостям та тенденціям розвитку ринку праці.

Аналіз цільової аудиторії для даного проєкту проведено за методикою Шеррингтона 5W, яка дає відповідь на наступні запитання для кожного окремого сегменту ((1) учні 9-11 класів, (2) батьки учнів 9-11 класів, (3) студенти, (4) молодці фахівці без досвіду роботи, (5) молодці фахівці, які отримали перший досвід роботи та прийняли рішення про зміну професії): 


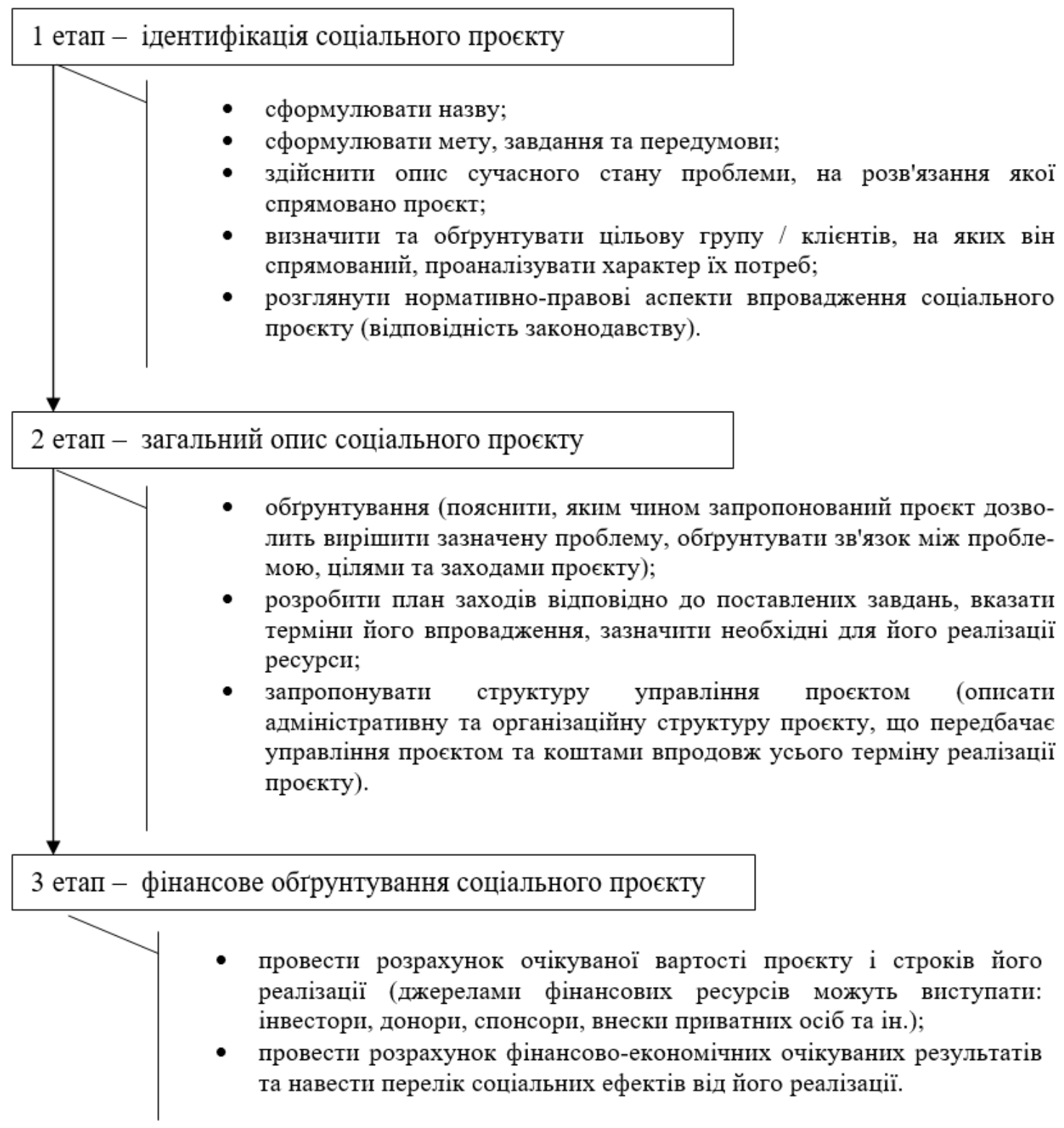

Джерело: Складено на основі $[8,14,17]$.

Рисунок 2. Етапи розроблення проєктної пропозиції та документації соціального проєкту

1) What? Що ми пропонуємо?

2) Why? Навіщо це потрібно?

3) When? Коли і в яких ситуаціях необхідна наша послуга?

4) Where? Де клієнти знайомляться з нашою послугою? Де відбувається рішення про заказ послуги?

Нормативно-правові аспекти впровадження соціального проєкту (відповідність законодавству) грунтуються, в першу чергу, на наступних актах: Закон України «Про зайнятість населення», Закон України «Про сприяння соціальному становленню та розвитку молоді в Україні», Закон України «Про загальнообов’язкове державне соціальне страхування на випадок безробіття», Програма сприяння безпечній життєдіяльності у сфері соціального захисту населення м. Харкова на 2017-2020 роки, Програма зайнятості населення Харківської області на період до 2020 року та ін. Аналізуючи нормативно-правову складову ринку праці України, можна стверджувати, що чинне законодавство є застарілим та не відповідає сучасним реаліям в країні. Більшість нормативно-правових актів несуть лише декларативний характер, через що виникає потреба у більшій змістовності кожного з законів. Тому, неповнота та фрагментарність законодавчої складової ринку праці зумовлює низку проблем, які ми і спостерігаємо в наш час. 
1 етап - загальний опис соціального проєкту.

Проєкт орієнтований на систематичну та всебічну роботу з молоддю починаючи з років школярства до професійного становлення.

Соціальний проєкт «Стартуємо разом!» охоплює наступні етапи:

1 етап: передбачає роботу з учнями 9-11 класів та їх батьками. На даному етапі соціальний проєкт допомагає зрозуміти школярам власні нахили та потреби і знайти шляхи їх вдалої реалізації у вигляді майбутньої професії, а їх батькам - тенденції сучасного ринку праці, нові професії та допомогти зробити дитині вибір щодо вступу у певний навчальний заклад та обрати спеціальність відповідно до його побажань. Для цього фахівці НКЦ «Вдалий старт» будуть надавати інформаційні послуги щодо потреб та сучасних тенденцій ринку праці в умовах мережевої економіки та впливу інформаційнокомунікаційних технологій. Також пропонується впровадити послуги профорієнтаційного тестування за ліцензійною програмою «Профкар’єра» за результатами якого виявляються схильності та особистісні професійно важливі якості молоді з подальшою поглибленою консультацією щодо вибору начального закладу. Вчасний та комплексний підхід до профорієнтаційної роботи під час навчання в школі, дозволяє запобігти наслідкам неправильного вибору, а значить і зменшити рівень безробіття серед молоді в Україні.

2 етап: сприяє розумінню тенденцій сучасного ринку праці, різноманіттю назв та компетентностей нових професій; опануванню навички soft-skills для підвищення конкурентоздатності молоді на ринку праці. Заходи з розвитку навичок soft-skills (тренінги, семінари, майстер-класи) сприяють підвищенню рівня емоційного інтелекту та відповідно комунікативним навичкам та навичкам міжособистісного спілкування, вмінню формулювати цілі, працювати в команді.

3 етап: зараджує випускникам закладів професійної та вищої освіти знайти вдале перше робоче місце, яке буде запорукою гідного рівня життя, відповідати отриманій спеціальності та сучасним потребам економіки. для цього проєктом передбачено підбір вакансій для випускників навчальних закладів, згідно побажань та результатів діагностики «Профорієнтатор-UA», допомога у написанні резюме та мотиваційного письма. Також проведення заходів з підвищення навичок із працевлаштування (тренінги, семінари, майстер-класи).

4 етап: допомагає змінити професію / посаду на нову, яка буде запорукою гідного рівня життя, відповідати внутрішним потребам. Вибрати професію один раз і на все життя - непросте завдання. Якщо молода людина помилась і усвідомила помилковий вибір тоді фахівці центру допоможуть відповісти на такі питання: чим хочеться займатися? що потрібно для цього зробити? Яку освіту або навички для цього необхідні (провести їх аналіз та в разі нестачі розробити план розвитку)? Проаналізувавши ситуацію, яка склалась, та розробивши план дій, фахівці центру допоможуть та навчать як знайти нову роботу.

Профорієнтаційна допомога та кар'єрне консультування повинне бути системним та доступним протягом усього періоду професійної діяльності.

Для реалізації соціального проєкту «Стартуємо разом!», в першу чергу, необхідні організаційні та людські ресурси.

Організаційна структура НКЦ «Вдалий старт» наведена на Рисунку 3.

Керівник НКЦ «Вдалий старт»:

- організовує навчально-виробничий процес, забезпечує створення умов для надання послуг;

- $\quad$ представляє Центр в органах державної влади, установах, організаціях і закладах, розпоряджається в установленому порядку його майном і коштами, приймає рішення про утворення структурних підрозділів; 


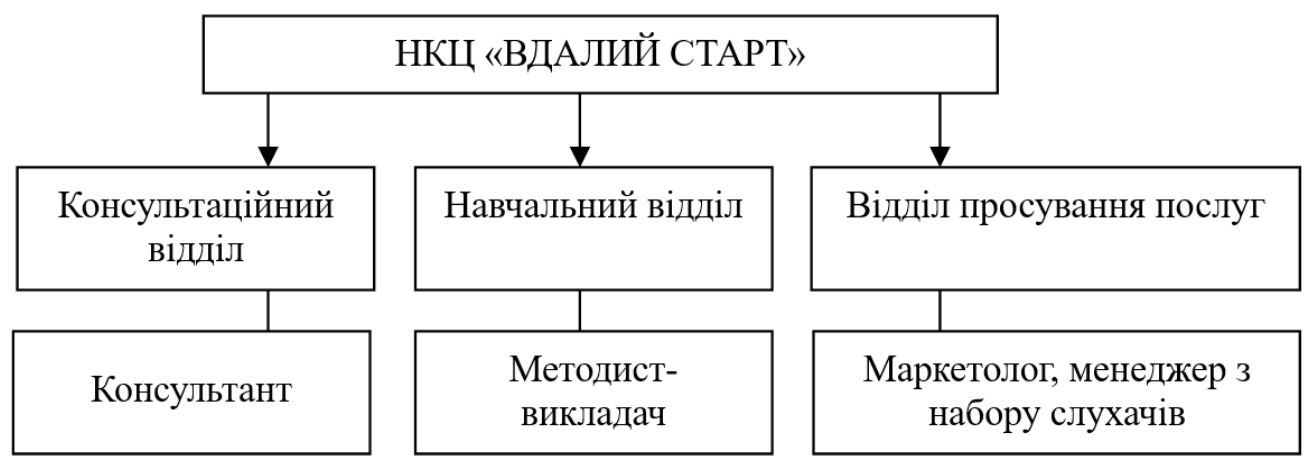

Джерело: Власна розробка авторів

Рисунок 3. Організаційна структура НКЦ «Вдалий старт»

- у межах компетенції видає накази, затверджує функціональні обов’язки працівників, приймає i звільняє з роботи працівників Центру, вживає заходів заохочення та дисциплінарних заходів;

- затверджує правила внутрішнього розпорядку;

- здійснює координацію та контроль за процесом;

- здійснює заходи щодо поліпшення умов праці, дотримання правил техніки безпеки, вимог санітарної і пожежної безпеки;

- відповідає за ведення бухгалтерського та статистичного обліку, складання звітності і подання їі в установлені терміни відповідним органам;

- укладає договори;

- здійснює інші повноваження, передбачені власним положенням Центру, з урахуванням вимог чинного законодавства.

Загальна чисельність співробітників НКЦ «Вдалий старт» на момент відкриття планується 6 осіб: заступник начальника управління; маркетолог, менеджер з набору слухачів; практичний психолог, HRфахівець; практичний психолог, тренер. Фахівці для роботи в центрі набирається на конкурсній основі з числа професіоналів в областях у відповідності до завдань. Розмір оплати плати встановлюється виходячи з середнього розміру заробітної плати даної посади у даному регіоні.

Керівник виконує наступні функції: координація роботи організації, побудова системи взаємовідносин з клієнтами, набір персоналу, моніторинг, аналіз і планування діяльності організації.

В обов'язки тренеру центру входить безпосередньо навчання слухачів на тренінгах та курсах, а в обов'язки консультантів (практичний психолог, HR-фахівець) - проведення діагностики та консультування клієнтів з використанням комплексу «Профкар’єра-UA».

Менеджер з продажу послуг виконує такі функції:

1) налагодження ділових зв’язків;

2) пошук клієнтів;

3) ведення клієнтської бази, контакти з замовниками;

4) укладення договорів і контрактів на навчання.

Крім того, в штаті присутній адміністратор.

Крім цього обов’язково потрібно ознайомитися з вимогами щодо дотримання певних правил і нормативів, що пред'являються до даного виду діяльності місцевими органами самоврядування. Так як основна діяльність НКЦ «Вдалий старт» буде спрямована на розвиток особистісних та професійних здібностей без видачі документів про освіту, то ліцензія на роботу НКЦ «Вдалий старт» не потрібна. 
План-графік реалізації проєкта передбачає наступні складові: завдання, термін виконання, обсяг робіт, фінансові ресурси, хто виконує. Основні завдання: дизайн та ремонт приміщення, придбання обладнання, підбір та оплата праці фахівців, розробка вебсайту та сторінки у соціальних мережах, проведення навчання працівників НКЦ «Вдалий старт» щодо використання в роботі профорієнтаційного тестування за ліцензійною програмою «Профорієнтатор UA», купівля профорієнтаційних інструментів та методик за ліцензійною програмою «Профорієнтатор-UА», відкриття центру.

Основні вимоги до розміщення навчальних приміщень центру:

1) наявність інженерних комунікацій, інтернету та ін.;

2) коридор повинен забезпечувати вільний вихід слухачів з усіх класів;

3) площа навчальних класів і використовувана в них меблі повинні забезпечувати вільну трансформацію простору для проведення презентацій, групових занять, конференцій;

4) вибір приміщень здійснюється виходячи 3 найбільшої близькості до зупинок громадського транспорту, бажано в центрі міста або великого житлового масиву (місце знаходження Департаменту відповідає зазначеним вимогам).

Важливою складовою для старту проєкту є придбання обладнання. Наприклад, для НКЦ «Вдалий старт» потрібно придбати: інтерактивну панель, портативний компютер (ноутбук), Wi-Fi роутер або мережевий комутатор-маршрутизатор Ethernet 3 підтримкою потокового відео $(2 \mathrm{Mb} / \mathrm{s})$ та роботи 20 користувачів одночасно, багатофункціональний пристрій з витратними матеріалами лазерний повинен забезпечувати друкування, сканування та копіювання документів і матеріалів та інші.

Проведення навчання працівників НКЦ «Вдалий старт» щодо використання в роботіпрофорієнтаційного тестування за ліцензійною програмою «Профорієнтатор UA» передбачає проходження семінарів для керівників, спеціалістів у м. Київ.

3 етап - фінансове обгрунтування соціального проєкту.

Основні фінансові витрати передбачають: дизайн та ремонт приміщення; придбання обладнання; витрати на оплату праці штатних працівників центру; розробка вебсайту та сторінки у соціальних мережах; навчання працівників НКЦ щодо використання в роботі профорієнтаційного тестування за ліцензійною програмою «Профорієнтатор UA»; купівля профорієнтаційних інструментів та методик за ліцензійною програмою «Профорієнтатор-UA»; витрати на відкриття центру.

Доцільність реалізації соціального проєкту «Стартуємо разом!» наведена у Таблиці 2.

Таблиця 2. Критерії оцінки доцільності реалізації соціального проєкту «Стартуємо разом!»

Джерело: Складено на основі [1, 10, 11]

\begin{tabular}{|c|c|}
\hline Критерій доцільності & Характеристика \\
\hline $\begin{array}{l}\text { Відповідність соціального } \\
\text { проєкту «Стартуємо разом!» } \\
\text { пріоритетним напрямам розвитку }\end{array}$ & $\begin{array}{l}\text { Відповідає Державній цільовій соціальній програмі «Молодь України» на 2016-2020 роки та } \\
\text { Стратегії розвитку державної молодіжної політики на період до } 2020 \text { року; Міській програмі } \\
\text { «Млодь Харкова» на 2018-2021 роки, отже проєкт має доцільність реалізації через } \\
\text { відповідність пріоритетним напрямам соціального розвитку України та харківської області. }\end{array}$ \\
\hline Соціальна резонансність & $\begin{array}{l}\text { Результати проєкту відчутні для поліпшення якості життя значного прошарку громадян - } \\
\text { молоді м. Харкова та області. Кожен за планований захід за своєю змістовністю на виході } \\
\text { проміжним продуктом, здатним змінити чинну соціальну ситуацію, задовольняючи } \\
\text { потреби більшої кількості людей, ніж цільова група (бенефіціари). Цее нові знання, вміння, } \\
\text { навички; корисні, соціально значимі зв'язки, знайомства, можливості комунікації, взаємодії, } \\
\text { партнерства. Саме такі «проміжні виходи» впливають на результат проєкту «Стартуємо } \\
\text { разом!», створюючи більш масштабний корисний ефект. }\end{array}$ \\
\hline
\end{tabular}


Таблиця 2 (продовження).

\begin{tabular}{|c|c|}
\hline Критерій доцільності & Характеристика \\
\hline $\begin{array}{l}\text { Відповідність соціального проєкту } \\
\text { «Стартуємо разом!» цілям і } \\
\text { потребам зацікавлених сторін }\end{array}$ & $\begin{array}{l}\text { Споживачі (учні 9-11 класів; батьки учнів 9-11 класів; студенти; молодці фахівці без } \\
\text { досвіду роботи; молодці фахівці, які отримали перший досвід роботи та прийняли } \\
\text { рішення про зміну професії); } \\
\text { громадкість (зниження рівня безробіття серед молоді, підвищення рівня зайнятості, } \\
\text { збільшення ВВП); } \\
\text { роботодавці (сприяння вирішенню кадрових питань підприємств, які здійснюють } \\
\text { діяльність на території області). }\end{array}$ \\
\hline $\begin{array}{l}\text { Значущість (цінність) результатів } \\
\text { реалізації проєкту «Стартуємо } \\
\text { разом!» }\end{array}$ & $\begin{array}{l}\text { Можна визначити як вигоду, котру отримують всі заінтересовані сторони у випадку } \\
\text { реалізації проєкту. Це пов'язано з тим, що виконується вимога гармонізації цінності } \\
\text { результатів проєкту, з двох аспектів - гармонізація зі стратегічними цілями організації, } \\
\text { що реалізує даний проєкт, та гармонізацію цінностей всіх зацікавлених сторін (споживачі, } \\
\text { громадкість, роботодавці). }\end{array}$ \\
\hline $\begin{array}{l}\text { Тривалість, сталість результатів } \\
\text { соціального проєкту }\end{array}$ & $\begin{array}{l}\text { Витрачені ресурси не просто забезпечують очікуваний ефект, але й продовжують у } \\
\text { певному періоді позитивно впливати на представників цільової групи, отримувачів } \\
\text { послуг (молодь). Тривалість, стійкість проєкту «Стартуємо разом!» можна визначати } \\
\text { за показниками: поява стійких взаємозв'язків або мереж та створення інноваційних } \\
\text { соціальних технологій. В рамках реалізації проєкту планується його просування } 3 \\
\text { використанням соціальних мереж (Facebook, YouTube, Instagram, Telegram). }\end{array}$ \\
\hline Мультиплікативність досвіду & $\begin{array}{l}\text { Доведена доцільність реалізації проєкту «Стартуємо разом!» тому що напрацювання } \\
\text { проєкту можуть бути використані в інших організаціях, громадах, на територіях. } \\
\text { Інструменти, методичні розробки, засоби інформаційного характеру проєкту «Стартуємо } \\
\text { разом!» можуть бути застосовані з метою забезпечення поширення (перенесення, } \\
\text { тиражування) результатів проєкту в інші організації, громади, території. }\end{array}$ \\
\hline
\end{tabular}

«Суспільні проєкти дають змогу забезпечити економічний розвиток через покращення соціального стану суспільства», - зазначає Бугрова. Отже, у Таблиці 3 авторами угруповано показники соціальноекономічної ефективності соціального проєкту «Стартуємо разом!» (складено на основі $[1,2,11])$.

Таким чином, обгрунтована проєктна пропозиція та документація як перший етап технології розробки та реалізації соціальних проєктів довела можливість досягнення мети соціального проєкту «Стартуємо разом!» - надати всебічну допомогу молоді щодо вирішення питань працевлаштування шляхом обгрунтованого вибору ЗВО та спеціальності (що віддзеркалюють його схильності, побажання та потреби сучасного ринку праці) та професії (що відповідає отриманій освіті та $є$ перспективною для вдалого старту кар'єри) у навчально-консультаційному центрі (НКЦ) для молоді «Вдалий старт».

Таблиця 3. Соціально-економічна ефективність соціального проєкту «Стартуємо разом!»

Джерело: Складено на основі $[1,2,11]$.

\begin{tabular}{|c|c|}
\hline Група показників & Назва показників \\
\hline $\begin{array}{l}\text { Статистичні } \\
\text { показники }\end{array}$ & $\begin{array}{l}\text { вбільшення рівня економічної активності молоді, \%; } \\
\text { збільшення рівня зайнятості молоді, \%; } \\
\text { вниження рівня безробіття серед молоді, \%; } \\
\text { вниження середньої тривалості пошуку роботи безробітними, місяців; } \\
\text { зменшення навантаження зареєстрованих безробітних на одну вакансію, осіб; } \\
\text { збільшення середньооблікової кількості штатних працівників, тис. осіб; } \\
\text { збільшення коефріцієнту обороту робочої сили по прийому, \%; } \\
\text { вниження коефіцієнту обороту робочої сили по звільненню, \%; } \\
\text { вбільшення середньомісячної номінальної заробітної плати, грн; } \\
\text { збільшення середньомісячної реальної заробітної плати, грн; } \\
\text { зменшення числа вибулих (вибуття) за рік за межі країни, осіб; } \\
\text { збільшення числа народжуваності, осіб; } \\
\text { активізація інтересу учнів до вибору професії; } \\
\text { усвідомлений вибір майбутньої профресії та професійне самовизначення. }\end{array}$ \\
\hline $\begin{array}{l}\text { Соціально- } \\
\text { економічна } \\
\text { ефективність для } \\
\text { молодих осіб }\end{array}$ & $\begin{array}{l}\text { вибір сорери професійної діяльності відповідно до своїх можливостей, здібностей і } 3 \\
\text { урахуванням вимог ринку праці; } \\
\text { отримання сучасних компетенцій; } \\
\text { отримання навичок Soft skills; } \\
\text { підвищення рівня емоційного інтелекту молоді; } \\
\text { гідна робота; } \\
\text { усвідомлений розвиток кар'єри; } \\
\text { матеріальна захищеність та стабільність. }\end{array}$ \\
\hline
\end{tabular}


Таблиця 3 (продовження).

\begin{tabular}{|c|c|}
\hline Група показників & Назва показників \\
\hline $\begin{array}{l}\text { Соціально- } \\
\text { економічна } \\
\text { ефективність для } \\
\text { організації }\end{array}$ & $\begin{array}{ll}\text { - } & \text { збільшення продуктивності праці молодих працівників; } \\
\text { • } & \text { поліпшення фрінансових показників роботи підприємства; } \\
\text { - } & \text { підвищення ролі матеріальної та нематеріальної мотивації; } \\
\text { - } & \text { сталий та комфорортний морально-психологічний клімат у колективі. }\end{array}$ \\
\hline
\end{tabular}

\section{ВИСНОВКИ}

Забезпечення гідного рівня життя громадян, особливо вразливих груп населення, потребує якісних, інноваційних змін у житті суспільства. Сучасним інструментом вирішення проблем та забезпечення стійкого розвитку $є$ соціальні проєкти. Однак, соціальне проєктування є складною, системною, багатоетапною технологією. Отже, одержані в ході дослідження результати, дозволили вирішити важливе наукове завдання - вдосконалити технологію розробки та реалізації соціальних проєктів, а також практичне - обгрунтувати проєктну пропозицію та документацію.

У ході дослідження одержано такі результати:

1) удосконалена класифікація соціальних проєктів за рахунок доповнення двома класифікаційними ознаками: «елементи соціальної інфраструктури» та «цільова група вразливих верств населення», що дає можливість враховувати спрямованість соціального проєкту при розробці проєктної пропозиції та документації, а також визначенні джерел фінансування;

2) удосконалена технологія розробки та реалізації соціальних проєктів за рахунок упорядкування та уточнення послідовності й змісту відповідних етапів (розроблення проєктної пропозиції та документації; підготовчий; функціональний; підсумовуючий). Запропонований підхід відповідає досвіду провідних країн та критеріям експертного оцінювання та забезпечує можливість ії використання як прикладного інструменту вирішення суспільних проблем та забезпечення стійкого розвитку;

3) обгрунтування проєктної пропозиції та документації проведено на прикладі соціального проєкту «Стартуємо разом!». Це дозволило провести апробацію запропонованої технології, та визначити, що запропонована технологія розробки та реалізації соціальних проєктів є ефективною та доцільною.

Перспективи подальших наукових досліджень полягають в поглибленні окремих складових технології розробки та реалізації соціальних проєктів з метою підвищення їх якості, основних критеріїв оцінки доцільності їх реалізації, соціально-економічної ефективності.

\section{AUTHOR CONTRIBUTIONS}

Conceptualization: Nataliia Ahramakova.

Data curation: Svitlana Honcharova.

Formal analysis: Nataliia Ahramakova, Svitlana Honcharova, Andriy Honcharov.

Funding acquisition: Nataliia Ahramakova, Svitlana Honcharova, Andriy Honcharov.

Methodology: Nataliia Ahramakova.

Project administration: Svitlana Honcharova.

Validation: Svitlana Honcharova.

Visualization: Svitlana Honcharova, Andriy Honcharov.

Writing - original draft: Nataliia Ahramakova, Svitlana Honcharova, Andriy Honcharov.

Writing - review \& editing: Nataliia Ahramakova, Svitlana Honcharova, Andriy Honcharov. 


\section{СПИСОК ЛІТЕРАТУРИ}

1. Antoniuk, D., \& Bui, Ju. (2019). Social innovations: experience on implementation of projects of the leading world countries for Ukraine. Management and Entrepreneurship: Trends of Development, 1(07), 64-73. (In Ukrainian). https://doi.org/10.26661/2522-1566/2019-1/0707

2. Bezpalko, O. (2010). Sotsialne proektuvannia [Social engineering] (127 p.). Kyiv: Znannia. (In Ukrainian). Retrieved from http://elibrary. kubg.edu.ua/id/eprint/2615

3. Bughrova, O. (2018). Socio-economic development by means of public projects delivery. Scientific Papers NaUKMA. Economics, 3, 14-20. (In Ukrainian). https://doi.org/10.18523/2519-4739312018148770

4. Cherneta, S., \& Nezbrycjka, O. (2018). Approaches to the definition of the concept «social project». Naukovyi chasopys Natsionalnoho pedahohichnoho universytetu imeni M. P. Drahomanova. Seriia 11: Sotsialna robota. Sotsialna pedahohika - Scientific journal of the National Pedagogical University named after MP Drahomanov. Series 11: Social work. Social pedagogy, 24(1), 228-236. (In Ukrainian). Retrieved from http://nbuv.gov.ua/UJRN/Nchnpu_011_2018_24(1)_34

5. Filimonova, O., \& Shynkarjuk, A. (2017). Financing of social projects for disabled people in ukraine and Poland. Financial Space, 1, 103-113. (In Ukrainian). Retrieved from https://fp.cibs.ubs.edu.ua/index.php/fp/article/view/507

6. Grant management (n.d.). Public group. Retrieved from https://www.facebook.com/groups/grant.management

7. GURT Resource Center (n.d.). Official web-site. Retrieved from https://gurt.org.ua

8. Hevchuk, N. (2017). Technology of development of social project. Zbirnyk naukovykh prats Kamianets-Podilskoho natsionalnoho universytetu imeni Ivana Ohiienka. Seriia: Sotsialno-pedahohichna - Collection of scientific works of Kamyanets-Podilsky National University named after Ivan Ogienko. Series: Socio-pedagogical, 29, 5-14. (In Ukrainian). Retrieved from http://nbuv.gov.ua/UJRN/znpkp_sp_2017_29_3

9. International Renaissance Foundation (n.d.). Konkursy ta hranty [Competitions and grants]. (In Ukrainian). Retrieved from https://www. irf.ua/grants/contests

10. Kropelnytska, S., Myhovych, T., \& Kylesha-Liubinets, M. (2019). Development and realization of social projects in Ukraine. State and regions. Series: Economics and Business, 1, 37-43. (In Ukrainian). Retrieved from http://www.econom.stateandregions.zp.ua/journal/2019/1_2019/8.pdf

11. Londar, S., Londar, L., \& Brynjuk, O. (2018). Features of the preparation and implementation of the world bank projects, taking into account the requirements of the updated environmental and social policies «environmental and social framework (esf)». Educational analytics of Ukraine, 3, 17-32. (In Ukrainian). Retrieved from http://nbuv.gov.ua/UJRN/educanalukr_2018_3_3

12. Nagorna, Gh. (2017). Choice the evaluation criteria in the process of social projecting. Derzhavne budivnyctvo - State building, 1. (In Ukrainian). Retrieved from http://www.kbuapa.kharkov.ua/e-book/db/2017-1/doc/5/03.pdf

13. NGO Information Analytical Center «Civic Space» (n.d.). Official web-site. Retrieved from https://www.prostir.ua

14. Panchyshyn, O. (2019). Special features of special objects for socially independent population groups. Mistobuduvannja ta terytorialjne planuvannja - Urban development and land use planning, 69, 320-329. (In Ukrainian). Retrieved from http://nbuv.gov.ua/UJRN/ MTP_2019_69_35

15. Science-Community.org (n.d.). Konkursy sotsialnykh proektiv na 2020 rik [Competitions of social projects for 2020]. (In Ukrainian). Retrieved from https://www.science-community.org/ru/grants/contests-by-type/social-contests

16. Shkuro, V. (2012). Typolohiia sotsialnykh proektiv [Typology of social projects]. Bulletin of Taras Shevchenko National University of Kyiv: Psychology. Pedagogy. Social Work, 6, 81-84. (In Ukrainian). Retrieved from http://nbuv.gov.ua/UJRN/vknuppcr_2012_6_28

17. Synjuk, N. (2019). Monitoring of social projects as a technology of complex scientific support. Zbirnyk naukovykh prats KamianetsPodilskoho natsionalnoho universytetu imeni Ivana Ohiienka. Seriia: Sotsialno-pedahohichna - Collection of scientific works of KamyanetsPodilsky National University named after Ivan Ogienko. Series: Socio-pedagogical, 33, 144-156. (In Ukrainian). Retrieved from http://nbuv. gov.ua/UJRN/znpkp_sp_2019_33_15

18. Ukrainian Cultural Foundation (n.d.). Official web-site. Retrieved from https://ucf.in.ua/ 